\title{
QUEEN'S
UNIVERSITY
BELFAST
}

\section{Mitochondrial DNA haplotype analysis of liver fluke in bison from Bialowieza Primaeval Forest indicates domestic cattle as the likely source of infection}

Walker, S. M., Prodöhl, P. A., Brennan, G., Fairweather, I., Hoey, E. M., Trudgett, A., Demiaszkiewicz, A. W., Kozak, M., Wedrychowicz, H., \& Teofanova, D. (2013). Mitochondrial DNA haplotype analysis of liver fluke in bison from Bialowieza Primaeval Forest indicates domestic cattle as the likely source of infection. Veterinary Parasitology, 191(1-2), 161-164. https://doi.org/10.1016/j.vetpar.2012.08.002

\section{Published in:}

Veterinary Parasitology

\section{Document Version:}

Peer reviewed version

Queen's University Belfast - Research Portal:

Link to publication record in Queen's University Belfast Research Portal

\section{Publisher rights}

Copyright 2013 Elsevier.

This manuscript is distributed under a Creative Commons Attribution-NonCommercial-NoDerivs License

(https://creativecommons.org/licenses/by-nc-nd/4.0/), which permits distribution and reproduction for non-commercial purposes, provided the author and source are cited.

\section{General rights}

Copyright for the publications made accessible via the Queen's University Belfast Research Portal is retained by the author(s) and / or other copyright owners and it is a condition of accessing these publications that users recognise and abide by the legal requirements associated with these rights.

\section{Take down policy}

The Research Portal is Queen's institutional repository that provides access to Queen's research output. Every effort has been made to ensure that content in the Research Portal does not infringe any person's rights, or applicable UK laws. If you discover content in the

Research Portal that you believe breaches copyright or violates any law, please contact openaccess@qub.ac.uk. 


\section{Accepted Manuscript}

Title: Mitochondrial DNA haplotype analysis of liver fluke in bison from Bialowieza Primeval Forest indicates domestic cattle as the likely source of infection

Authors: Stephen M. Walker, Aleksander W. Demiaszkiewicz, Monika Kozak, Halina Wedrychowicz, Denitsa Teofanova,

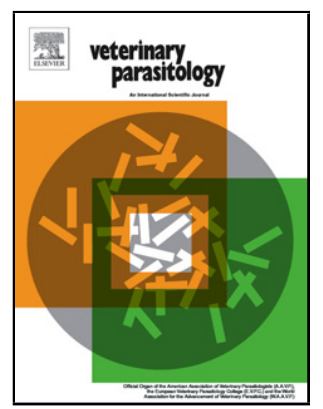

Paulo Prodohl, Gerry Brennan, Ian Fairweather, Elizabeth M. Hoey, Alan Trudgett

PII: $\quad$ S0304-4017(12)00415-3

DOI: $\quad$ doi:10.1016/j.vetpar.2012.08.002

Reference: $\quad$ VETPAR 6473

To appear in: $\quad$ Veterinary Parasitology

Received date: $\quad 11-1-2012$

Revised date: $\quad 12-6-2012$

Accepted date: $\quad$ 2-8-2012

Please cite this article as: Walker, S.M., Demiaszkiewicz, A.W., Kozak, M., Wedrychowicz, H., Teofanova, D., Prodohl, P., Brennan, G., Fairweather, I., Hoey, E.M., Trudgett, A., Mitochondrial DNA haplotype analysis of liver fluke in bison from Bialowieza Primeval Forest indicates domestic cattle as the likely source of infection, Veterinary Parasitology (2010), doi:10.1016/j.vetpar.2012.08.002

This is a PDF file of an unedited manuscript that has been accepted for publication. As a service to our customers we are providing this early version of the manuscript. The manuscript will undergo copyediting, typesetting, and review of the resulting proof before it is published in its final form. Please note that during the production process errors may be discovered which could affect the content, and all legal disclaimers that apply to the journal pertain. 


\section{Mitochondrial DNA haplotype analysis of liver fluke in bison from Bialowieza}

2 Primeval Forest indicates domestic cattle as the likely source of infection.

3

4 Stephen M. Walker ${ }^{1}$, Aleksander W. Demiaszkiewicz ${ }^{2}$, Monika Kozak ${ }^{2}$, Halina

5 Wedrychowicz $^{2}$, Denitsa Teofanova ${ }^{3}$, Paulo Prodohl ${ }^{1}$, Gerry Brennan ${ }^{1}$, Ian

6 Fairweather $^{1}$, Elizabeth M. Hoey ${ }^{1}$, and Alan Trudgett ${ }^{1}$.

$9{ }^{1}$ School of Biological Sciences, The Queen's University of Belfast, 97 Lisburn road,

10 Belfast, N. Ireland.

$11{ }^{2}$ Polish Academy of Science, Molecular Parasitology Laboratory, W Stefanski Institute

12 of Parasitology, PL-00818 Warsaw, Poland

$13{ }^{3}$ Institute of Experimental Pathology and Parasitology-BAS, 25 “Akad. Georgi

14 Bonchev", 1113 Sofia, Bulgaria.

* corresponding author

18 Abstract

19 We have determined the mitochondrial genotype of liver fluke present in Bison (Bison

20 bonasus) from the herd maintained in the Bialowieza National Park in order to

21 determine the origin of the infection. Our results demonstrated that the infrapopulations

22 present in the bison were genetically diverse and were likely to have been derived from

23 the population present in local cattle. From a consideration of the genetic structure of

24 the liver fluke infrapopulations we conclude that the provision of hay at feeding stations 
may be implicated in the transmission of this parasite to the bison. This information may be of relevance to the successful management of the herd.

Key words: Bison; Fasciola hepatica; genetic diversity; Bialowieza.

\section{Introduction}

The Bialowieza Primeval Forest (52 $\left.45^{\prime} 53^{\prime \prime} \mathrm{N}, 23^{\circ} 51^{\prime} 39^{\prime \prime} \mathrm{E}\right)$ covers an area of approximately $1500 \mathrm{~km}^{2}$ and straddles the border between Poland and Belarus. It is characterised by stands of trees that are considered to be representative of those once present over much of prehistoric northern Europe (Falinski, 2003) and supports a wide variety of native European fauna, although management as a game reserve in previous centuries has led to the extinction of some predators (such as the bear) and the introduction of some non-native species (Sidorovich et al., 1996). Its most famous "charismatic megafauna" is the European Bison, Bison bonasus and this species plays a significant role in maintaining the ecology of the forest (Jaroszewicz et al. 2009). There are two populations of bison, one in the Belarus part of the forest and the other in the Bialowieza National Park (BNP), a $100 \mathrm{~km}^{2}$ area of commercially unexploited forest on the Polish side of the border. The bison in the BNP are separated from farmland and domestic animals and their numbers are controlled to some extent by provision of winter fodder and culling. The native bison herd was exterminated in 1918 and reestablished using twelve animals (some of which were descendants of the Bialowieza bison) from zoological gardens in the 1950s. As a result of this process, the herd has very limited genetic diversity, with mitochondrial DNA studies indicating only three haplotypes (Wójcik et al., 2009) in 195 individuals. The herd's nuclear genome is 
similarly restricted, with only four alleles being found at the Major Histocompatibility

50 Complex (MHC) DRB3 locus in contrast to that in the American bison, Bison bison-

which, although also having suffered population bottle-necks, has 15 alleles (Radwan et al., 2007; Traul et al., 2005). The four alleles present in the Bialowieza herd, however, are highly divergent. The potential effects of loss of genetic variability and in particular restricted MHC variability on the survival of species have been recently reviewed

55 (Radwan et al., 2010a).

Since the early 1980s, male bison in the Bialowieza herd have been suffering from balanoposthitis, a chronic disease of the external genital organs associated with infection with Arcanobacterium spp. (Lehnen et al., 2006) and it has been postulated that this infection, which may endanger the herd, is a consequence of the lack of MHC

60 diversity (Udina and Shaikhaev, 1998). The Bialowieza herd is also susceptible to

61 infection by helminth parasites, with up to $44 \%$ of animals culled in 2001 carrying the

62 liver fluke, Fasciola hepatica (Kizeiwicz, 2008). In recent years, this incidence has

63 risen to $100 \%$ of adults, some of which show very heavy infections ( $>600$ flukes)

64 (Demiaszkiewicz et al., 2008). Infection with this parasite has been shown to modulate the host's immune system towards a T helper 2 cytokine profile (Brady et al., 1999). It has recently been proposed that this immunomodulatory effect may be due to secreted helminth molecules that mimic the action of mammalian cathelicidins and may act to reduce the inflammatory component of the immune response to bacterial infections

69 (Robinson et al. 2011). This raises the possibility that the balanoposthitis infection in the Bialowieza herd may become a chronic infection due to the presence of a concomitant liver fluke infection. In these circumstances, it is desirable to investigate the origin of the liver flukes present in these animals in order to devise strategies which 
may reduce the frequency of infection. We have determined the mitochondrial haplotypes of flukes from bison and cattle from the Bialowieza region and compared these with those seen in flukes from the wider northern European cattle population.

\section{Materials and Methods}

Flukes were obtained from bison culled in 2007 (Demiaszkiewicz et al. 2008) and transported in absolute alcohol. Approximately $25 \mathrm{~mm}^{3}$ of fluke tissue was placed into $500 \mu \mathrm{l}$ of $10 \% \mathrm{w} / \mathrm{v}$ Chelex ${ }^{\circledR}$ (Fluka) solution incorporating $10 \mu \mathrm{l}$ proteinase $\mathrm{K}$ (Sigma) at a concentration of $20 \mathrm{mg} / \mathrm{ml}$. This was heated at $55^{\circ} \mathrm{C}$ for one hour, followed by gentle vortexing and a further incubation at $95^{\circ} \mathrm{C}$ for 30 minutes. The mixture was gently vortexed and spun down at $10,000 \mathrm{~g}$ for 10 seconds. The $250 \mu \mathrm{l}$ of supernatant was taken, diluted 1:10 in deionised water and stored at $-20^{\circ} \mathrm{C}$. Details of the primers and procedures used for mitochondrial DNA analysis, data assembly and analysis of population structure have been given elsewhere (Walker et al. 2011a; Teofanova et al. 2011). The sequences of each unique haplotype from the Polish flukes samples were submitted to GenBank and have been assigned Accession numbers HM 487168 to HM 487199. The Bison fluke dataset was supplemented in analysis by sequences from five flukes from cattle from eastern Poland and 444 flukes from a Dutch fluke dataset. Details of the origin of these flukes and their Accession numbers are given elsewhere (Teofanova et al. 2011, Walker et al. 2011a). Median-Joining networks were calculated using "Network 4.5" (Flexus Technology Ltd) software which incorporates the algorithm developed Bandelt and colleagues (Bandelt et al., 1999). 
97

98

101

102

103

104

105

106

107

108

109

110

111

112

113

114

115

116

118

119 1

\section{Results}

98

A total of twenty-six sequences suitable for analysis were obtained from samples of the flukes present in the infrapopulations from six bison (number of flukes analysed per infrapopulation, 4,4,4,4,5,5). Following alignment and analysis, it was shown that the twenty-six flukes carried twelve distinct mitochondrial haplotypes. Within the population, the haplotypes followed a leptokurtic distribution, with the most common haplotype occurring eleven times, the two next most frequent five times and twice, respectively, and the remaining haplotypes being present in single flukes. There were twenty-nine polymorphic sites seen in the 1160 nucleotides present in the analysed sequences and the average number of nucleotide differences between pairs of samples (Pi) was 0.00605 . All mitochondrial sequences were consistent with the flukes being $F$. hepatica rather than $F$. gigantica or other fasciolids. Infrapopulations from individual bison generally contained several $(<4)$ haplotypes.

2 In order to investigate the genetic relationship between the flukes present in the bison and those present in local domestic cattle, the dataset was supplemented with flukes from Polish cattle and a Median Joining Network plotted (Figure 1a). This shows that the flukes from the bison were derived from two well-defined clades with almost all of the individual flukes being associated with the taxa forming the nucleus of the clade or separated from these taxa by only one or two nucleotide changes. The flukes from the local cattle were associated with only with one of these clades. In view of the possibility that the small number of Polish flukes from cattle present in the dataset could be distorting the analysis, we repeated it with the incorporation of a larger 
121 dataset $(\mathrm{N}=444)$ containing flukes from elsewhere in northern Europe. To simplify the

122 display, a "star contraction" of 3 was applied to the data before calculating the network:

123 this condenses minor nodes (differing by less than three nucleotide changes) within a

124 clade. Figure $1 \mathrm{~b}$ shows that, under these conditions, the Polish flukes from both cattle

125 and bison are associated with the two major clades seen with flukes from northern

126 Europe.

127

128 4. Discussion

129

131 (Demiaszkiewicz et al., 2008) is indicative of the general immunological "weakness" of

132 this population. The results presented in this study prove that the liver flukes are

133 Fasciola hepatica and that, although the establishment of the BNP has allowed the

134 preservation of many ancient flora and fauna, these parasites do not appear to be

135 distinctive and are drawn from the same population as that which is common in present-

136 day cattle and sheep in northern Europe (Walker et al. 2011a). The BNP is separated

137 from adjacent farmland by a fence which should have prevented the ingress of infected

138 cattle or sheep and the subsequent transmission of $F$. hepatica to local snail populations.

139 There are a number of possibilities with regard to the route by which the population of

140 F. hepatica described in this study may have become part of the Bialowieza forest eco-

141 system. Wild herbivorous animals may have acted as a vector; deer are plentiful in the

142 forest and have been reported to be infected with liver fluke in the past although a recent

143 study of forty-one deer found that only three showed evidence of fasciolosis

144 (Demiaszkiewicz, in preparation). Hares are known to act as vectors for liver fluke both 
145 in the Bialowieza region and elsewhere (Shimalov, 2001; Rondelaud et al., 2001).

146 However, infra-populations (the number of parasites in a single host) are typically small

147 in hares and rarely exceed three or four flukes (Shimalov, 2001; Walker et al. 2011b).

148 The diversity of haplotypes seen in the bison population is such that it would have

149 required multiple introductions by infected hares. This same argument would also be

150 valid with regard to the possibility that there had been an introduction of a population of

151 infected lymnaeid snail intermediate hosts. Although Polish lymnaeid snail populations

152 may have a high prevalence of infection (Kozak and Wędrychowicz, 2010) individual

153 snails are rarely infected by more than one or two miracidia (Kaplan et al., 1997) and

154 the asexual reproduction occurring at this stage of the life cycle acts to reduce genetic

155 diversity. The similarity of the mitochondrial haplotypes found in liver flukes from the

156 bison herd and those from cattle implicate cattle - directly or indirectly - in the

157 introduction of $F$. hepatica into the bison herd. Up to approximately fifty years ago

158 domestic cattle were grazed in the clearings of the Bialowieza National Park, however

159 heavy infection with liver fluke has only become evident in the last decade (Kizeiwicz,

160 2008), posing the question as to what was acting as the definitive mammalian host for

161 the parasite during the intervening years. Recruitment to the bison herd has been shown

162 to be related to climatic conditions, with the abundance of oak seeds (masting) in the

163 preceding year and the depth of snow in winter being major factors (Mysterud et al.,

164 2007). To ameliorate the effects of snowy weather, hay is provided at a number of

165 feeding sites, which leads to the bulk of the herd gathering at these sites during the

166 winter months. It is possible that the fluke may have been inadvertently introduced into

167 the forest as metacercariae on contaminated hay. Liver fluke metacercariae are known

168 to be able to remain infective on foliage for up to eight months at above $-10^{\circ} \mathrm{C}$ (Boray 
and Enigk, 1964). Hay sourced from local farms (Kowalczyk et al. 2011) would, if

170 contaminated with $F$. hepatica metacercariae, transmit a population of flukes derived

171 from the local cattle population; this would explain why the distribution of haplotypes

172 and diversity seen in the bison flukes resembles that of the cattle flukes.

173

Although the high prevalence of the fasciolosis in the bison herd means that the

175 infection is probably self-maintaining, the likely origin of the flukes in local farm stock

176 means that they will be amenable to anthelmintic drugs should it become necessary to

177 treat individual bison. The long-term benefits of providing winter feeding have been

178 questioned (Wolk and Krasińska, 2004, Kowalczyka et al., 2011), as the congregation

179 of animals round the feeding stations may be conducive to the spread of infectious and

180 parasitic diseases (Radwan et al., 2010b). The findings in this study and that of others

181 (Jaroszewicz et al., 2009) indicate that further consideration should be given to the

182 question of supplementary winter feeding and the source of such feed should be

183 controlled, not only with regard to seeds from non-native species (as it is at present) but

184 also for possible contamination with parasite propagules.

185

\section{Acknowledgements}

187

188 This study was supported financially by the DeLiver consortium of the European Union

189 VII Framework Programme (FOOD-CT-200X-023025).

190

$191 \quad$ References

192 
193 Bandelt, H.J., Forster, P., Röhl, A., 1999. Median-joining networks for inferring

194 intraspecific phylogenies. Mol. Biol. Evol. 16, 37-48.

195 Boray J.C., Enigk K., 1964. Laboratory studies on the survival and infectivity of 196 Fasciola hepatica and Fasciola gigantica metacercariae. Z. Tropenmed. 197 Parasitol. 15, 326-331.

198 Brady, M.T., O’Neill, S.M., Dalton, J.P., Mills K.H.G., 1999. Fasciola hepatica

199 suppresses a protective Th1 response against Bordetella pertussis. Infect.

$200 \quad$ Immun. 67, 5372-5378.

201 Demiaszkiewicz, A.W., Pyziel A.M., Lachowicz J., 2008. Helminthological status of

202 European Bison in the Bialowieza Forest in the winter 2007/2008. European

203 Bison Conservation Newsletter. 1, 42-52.

204 Falinski, J.B.., 2003. Bialowieza forest, a relict ecosystem in Poland and Belarus.

205 Biodiversity (Ottawa). 4, 18-27.

206 Jaroszewicz, B.; Pirozikow, E.; Sagehorn, R., 2009. Endozoochory by European bison

207 (Bison bonasus) in Bialowieza Primeval Forest across a management gradient.

$208 \quad$ Forest Ecol. Manag. 258, 11-17.

209 Kaplan R.M., Dame J.B., Reddy G.R., Courtney C.H., 1997. The prevalence of

210 Fasciola hepatica in its snail intermediate host determined by DNA probe assay.

211 Int. J. Parasitol. 27, 1585-1593.

212 Kiziewicz, B., 2008. Prevalence of Natural Infection with Liver Fluke Fasciola

213 hepatica (Linnaeus, 1758) in European Bison Bison bonasus in Bialowieza

214 Primeval Forest of Poland. X European Multicolloquium of Parasitology -

215 EMOP 10 Paris, France. Abstract 136. 
216 Kowalczyka, R,, Taberlet, P., Coissac, E., Valentini, A., Miquel, C., Kaminskia, T.,

217

218

219

220

221

222

223

224

225

226

227

228

229

230

231

232

233

234

Wójcika, J.M. 2011. Influence of management practices on large herbivore diet - Case of European bison in Białowieza Primeval Forest (Poland). Forest Ecology and Management 261, 821-828.

Kozak, M., Wędrychowicz, H., 2010. The performance of a PCR assay for field studies on the prevalence of Fasciola hepatica infection in Galba truncatula intermediate host snails. Vet. Parasitol. 168, 25-30.

Lehnen, A., Busse, H-J., Frölich, K., Krasinska, M., Kämpfer P., Speck, S., 2006. Arcanobacterium bialowiezense sp. nov. and Arcanobacterium bonasi sp. nov., isolated from the prepuce of European bison bulls (Bison bonasus) suffering from balanoposthitis, and emended description of the genus Arcanobacterium Collins et al. 1983. Int. J. Sys. Evol Micr. 56, 861-866.

Mysterud, A., Barton, K.A., Jedrzejewska, B., Krasinski, Z.A., Niedzialkowska, M., Kamler, J.F., Yoccoz, N.G., Stenseth, N.C., 2007. Population ecology and conservation of endangered megafauna: the case of European bison in Bialowieza Primeval Forest, Poland. Anim. Conserv. 10, 77-87.

Radwan, J., Kawalko, A., Wójcik, J.M., Babik, W., 2007. MHC-DRB3 variation in a free-living population of the European bison, Bison bonasus. Mol. Ecol.16, 531540. 
235 Radwan, J., Biedrzycka, A., Babik, W., 2010a. Does reduced MHC diversity decrease

236 viability of vertebrate populations? Biol. Conserv. 143, 537-544..

237 Radwan, J., Demiaszkiewicz, A.W., Kowalczyk, R., Lachowicz, J., Kawałko A.,

238 Wójcik, J.M., Pyziel, A.M., Babik, W. 2010b. An evaluation of two potential

239 risk factors, MHC diversity and host density, for infection by an invasive

240

241 nematode Ashworthius sidemi in endangered European bison (Bison bonasus) Biol. Conserv. 143, 2049-2053.

Robinson, M.W., Donnelly, S., Hutchinson, A.T., To, J., Taylor, N.L., Norton, R.S., Perugini, M.A., Dalton, J.P. 2011. A family of helminth molecules that modulate innate cell responses via molecular mimicry of host antimicrobial peptides. PLoS Pathog 7(5): e1002042. doi:10.1371/journal.ppat.1002042.

Rondelaud, D., Vignoles, P., Abrous, M., Dreyfuss, G., 2001. The definitive and intermediate hosts of Fasciola hepatica in the natural watercress beds in central France. Parasitol. Res. 87, 475-478.

Shimalov, V.V., 2001. Helminth fauna of the hare (Lepus europaeus Pallas, 1778) in the southern part of Belarus. Parasit. Res. 87, 85.

251 Sidorovich, V.E.; Jedrzejewska, B.; Jedrzejewski, W., 1996. Winter distribution and abundance of mustelids and beavers in the river valleys of Bialowieza Primeval Forest. Acta Theriol. 41, 155-170.

Teofanova, D., Kantzoura, V., Walker, S., Radoslavov, G., Hristov, P., Theodoropoulos, G., I. Bankov, I., Trudgett, A. 2010. Genetic diversity of liver flukes (Fasciola hepatica) from Eastern Europe. Infect. Genet. Evol. 11, 109115. 
258 Traul, D.L., Bhushan, B., Eldridge, J.A., Crawford, T.B., Li, H., Davies, C.J.,. 2005.

259 Characterization of Bison bison major histocompatibility complex class IIa 260 haplotypes. Immunogenetics. 57, 845-854.

261 Udina, I.G., Shaikhaev, G.O., 1998. Restriction fragment length polymorphism (RFLP)

262 of exon 2 of the MhcBibo-DRB3 gene in European bison Bison bonasus. Acta

263 Theriol. S5: 75-82.

264 Walker, S.M,, Johnston' C., Hoey E.M., Fairweather' I., Borgsteede, F., Gaasenbeek, C., 265 Prodöhl' P.A., A. Trudgett' A. 2011a. Population dynamics of the liver fluke, 266 Fasciola hepatica: the effect of time and spatial separation on the genetic 267 diversity of fluke populations in the Netherlands. Parasitol. 138, 215-223.

268 Walker, S.M., Johnston C, Hoey EM, Fairweather I, Borgsteede FH, Gaasenbeek CP, 269 Prodohl PA, Trudgett A. 2011b. Potential role of hares in the spread of liver 270 fluke in the Netherlands. Vet Parasitol. 177, 179-181.

271 Wójcik, J.M., Kawałko, A., Tokarska, M., Jaarola, M., Vallenback, P., Pertoldi, C., 272 2009. Post-bottleneck mtDNA diversity in a free-living population of European 273 bison: implications for conservation. J. Zool. 277, 81-87.

274 Wolk, E., Krasiñska, M., 2004. Has the condition of European bison deteriorated over 275 last twenty years? Acta Theriol. 49, 405-418.

276 


\section{Figure Legend}

277

278 Figure 1a. Median Joining Network for Polish flukes. White nodes - flukes from

279 Bison; black nodes - flukes from local cattle; red median vector node - virtual

280 (hypothetical) node. The size of each node is proportional to the number of

281 individual flukes bearing that haplotype. The distances between nodes are

282 proportional to genetic distance, as indicated by the positions of nucleotide

283 changes, which are shown by red numerals.

284

285 Figure 1b. Median Joining Network for Polish and other northern European Flukes.

286 Nodes containing haplotypes found in the Polish flukes from bison and cattle are

287 shown in grey, white nodes - other northern European cattle flukes.

288 
Figure Legend

Figure 1a. Median Joining Network for Polish flukes. White nodes - flukes from Bison; black nodes - flukes from local cattle; red median vector node - virtual (hypothetical) node. The size of each node is proportional to the number of individual flukes bearing that haplotype. The distances between nodes are proportional to genetic distance, as indicated by the positions of nucleotide changes, which are shown by red numerals.

Figure 1b. Median Joining Network for Polish and other northern European Flukes. Nodes containing haplotypes found in the Polish flukes from bison and cattle are shown in grey, white nodes - other northern European cattle flukes. 